\title{
Influence of Temperature and Relative Humidity on Sporulation of Cercospora zeae-maydis and Expansion of Gray Leaf Spot Lesions on Maize Leaves
}

\author{
P. A. Paul, Department of Plant Pathology, Iowa State University, Ames 50110; and G. P. Munkvold, Pioneer Hi- \\ Bred International, Johnston, IA 50131
}

\begin{abstract}
Paul, P. A., and Munkvold, G. P. 2005. Influence of temperature and relative humidity on sporulation of Cercospora zeae-maydis and expansion of gray leaf spot lesions on maize leaves. Plant Dis. 89:624-630.

Controlled environment studies were conducted to determine the effects of temperature on the expansion of lesions of gray leaf spot, and the effects of temperature and relative humidity on the sporulation of Cercospora zeae-maydis on maize (Zea mays). For the lesion expansion experiment, potted maize plants were spray inoculated at growth stage V6, bagged, and incubated at 25 to $28^{\circ} \mathrm{C}$ and $100 \%$ relative humidity for 36 to $40 \mathrm{~h}$. Symptomatic plants were transferred to growth chambers and exposed to constant temperatures of 25,30 , and $35^{\circ} \mathrm{C}$. Lesion area (length by width) was measured at 4-day intervals for 17 days. For sporulation studies, lesions were excised from naturally infected maize leaves, measured, and incubated at constant temperature $\left(20,25,30\right.$, or $\left.35^{\circ} \mathrm{C}\right)$ and relative humidity $(70,80,90$, or $100 \%)$ for $72 \mathrm{~h}$. Sporulation was estimated as the number of conidia per square centimeter of diseased leaf tissue. A quadratic function was used to model the relationship between log-transformed conidia per square centimeter at $100 \%$ relative humidity and temperature. Temperature had a significant effect on lesion expansion $(P \leq 0.05)$. At 25 and $30^{\circ} \mathrm{C}$, the rate of lesion expansion was significantly higher than at $35^{\circ} \mathrm{C}(P \leq 0.05)$. The largest lesions and the highest mean rate of lesion expansion were observed at $30^{\circ} \mathrm{C}$; however, the mean lesion expansion rate at this temperature was not significantly different from that at $25^{\circ} \mathrm{C}$. The interaction effect of temperature and relative humidity on the $\log$ of conidia per square centimeter of diseased tissue was significant $(P \leq 0.05)$. At $100 \%$ relative humidity, the effect of temperature on sporulation was significant $(P \leq 0.05)$, with maximum spore production occurring at 25 and $30^{\circ} \mathrm{C}$. The quadratic model explained between 49 and $80 \%$ of the variation in the log of conidia per square centimeter at $100 \%$ with variation in temperature. These results suggest that the rapid increase in gray leaf spot severity generally observed during mid- and late summer may be due to favorable conditions for lesion expansion during this period. When relative humidity is $>95 \%$, expanding lesions may serve as a source of inoculum for secondary infections.
\end{abstract}

Additional keyword: corn

Gray leaf spot, caused by Cercospora zeae-maydis Tehon \& E. Y. Daniels, is one of the most important foliar diseases of maize (Zea mays L.) worldwide (43). Since being first reported in Illinois in the 1920s (38), gray leaf spot has been observed in most of the maize-growing regions of the United States $(22,43)$. The increased prevalence of this disease coincides with the widespread adoption of conversation tillage (24), a practice which favors the overwinter survival of the fungus in crop residue on the soil surface $(10,11,29,30)$.

Although many aspects of gray leaf spot have been studied over the past 20 years, the relationship between environmental

Corresponding author: P. A. Paul
E- mail: paul.661@ osu.edu

Accepted for publication 11 February 2005.

DOI: 10.1094/PD-89-0624

() 2005 The American Phytopathological Society factors and specific components of the disease cycle are not fully understood. Most research has been conducted under field conditions, where confounding effects of uncontrolled edaphoclimatic factors may influence the relationship between environment and specific stages of the disease cycle. Based on empirical observations, moderate to high temperatures and prolonged periods of high relative humidity generally are accepted as being favorable for the development of this disease $(22,23,33,43)$. However, the level of gray leaf spot may differ among years and locations with similar weather and cropping conditions (28). Ringer and Grybauskas (32) suggested that environmental conditions during primary infection stages of the disease cycle were more important in determining the rate of disease progress than overall conditions during the growing season. Similarly, Paul (28) reported that the number of hours of daytime air temperature between 20 and $30^{\circ} \mathrm{C}$ and nighttime relative humidity $\geq 90 \%$ for the period between growth stages V4 and V12 were more highly correlated with gray leaf spot severity than overall mean temperature and relative humidity during the growing season.

The increase in gray leaf spot severity usually results from the occurrence of two distinct processes; an increase in the number of lesions per unit of leaf area through new infections and an increase in the size of the existing lesions through lesion expansion. The infection process depends on availability of inoculum (produced by sporulating lesions or sporulation on maize residues on the soil surface) and temperature and relative humidity $(3,4)$. Once these conditions are met, the progress of gray leaf spot is characteristic of a typical polycyclic disease (40), with more than one infection cycle during the growing season (12,32). Due to a long latent period $(3,32)$, very few infection cycles usually occur prior to the critical grain-fill period when the impact of the disease is most yield limiting. Ringer and Grybauskas (32) suggested that due to the long latent period (LP50 $=14$ to 19 days) and limited number of infection cycles, the amount of inoculum generated during the primary infection cycle was more important than the number of secondary cycles in determining final disease severity. These authors attributed the rapid increase in the rate of gray leaf spot development during the secondary infection cycle to the abundant production of conidia from the primary infection cycle and the occurrence of favorable weather conditions (rainfall and high relative humidity) between the primary and secondary infection cycles.

If the level of initial inoculum is high and conditions are favorable for primary infection, final disease severity may be high even though few secondary cycles occur. Even when conditions are unfavorable for secondary infection, the severity of gray leaf spot still increases once conditions are favorable for existing lesions to expand. Analyzing the importance of lesion expansion as an epidemic component, Berger et al. (5) identified three major consequences of lesion expansion: (i) increased development of disease even when host tissue is no longer susceptible to infection, (ii) increase in diseased leaf area under conditions unfavorable for infection, and (iii) an increase in the area available for production of inoculum. Relative to newly infected tissue, tissues colonized through lesion expansion require less time 
to sporulate because they do not require a latent period (5).

For several pathosystems, lesion expansion as a function of temperature has been used as an important component of disease simulation models $(2,6,34,41,42)$. Berger et al. (5) demonstrated through simulation modeling that a radial rate of lesion expansion of $0.1 \mathrm{~mm} \mathrm{day}^{-1}$ resulted in $>70 \%$ of the total diseased area being due to lesion expansion. Investigations on the effects of environmental conditions on expansion of gray leaf spot lesions and sporulation of the pathogen should enhance our understanding of the dynamics of this disease in the field. In addition, because these traits are commonly used in screening for gray leaf spot resistance $(17,20)$, breeding programs would benefit from increased knowledge of their response to environmental conditions. Hence, the objectives of this study were to (i) determine the effects of temperature on the rate of expansion of gray leaf spot lesions and (ii) determine the influence of temperature and relative humidity on spore production on diseased leaves.

\section{MATERIALS AND METHODS}

Temperature control. Growth chambers (Intellus Controller; Percival Scientific, Inc., Perry, IA) were used to maintain constant temperatures of 20,25,30, and $35^{\circ} \mathrm{C}$, representing temperatures within the range of the mean minimum and maximum daily ambient temperatures. Mean minimum and maximum temperatures are based on a summary of weather conditions in Iowa for the last 50 years obtained from the National Climate Data Center. These conditions commonly occur during mid- to late summer in south-central and southeastern Iowa, where gray leaf spot is most problematic. In each growth chamber, fluorescent and incandescent lights supplied a 12- to 14-h photoperiod, producing an intensity of $316 \mu \mathrm{mol} \mathrm{m} \mathrm{m}^{-2} \mathrm{~s}^{-1}$ at approximately $100 \mathrm{~cm}$ from the source. Alternating light and dark regimes were reported as being most favorable for in vitro sporulation $(4,22)$. Growth chambers were programmed to cool a few degrees during hours of illumination and reheat during hours of darkness to minimize differences in temperature between light and dark periods. Throughout this study, temperature and relative humidity within each growth chamber were monitored using HOBO dataloggers (Model H8 Pro Series; Onset Computer Corporation, Bourne, MA) recording at 5-min intervals.

Lesion expansion experiment. The effect of temperature on expansion of gray leaf spot lesions was investigated using potted plants subsequent to artificial inoculation. Seed of inbred B73 were planted (three per pot) in 20-cm-diameter pots in a steam-sterilized potting mixture of peat, perlite, and soil (1:2:1). Inbred B73 was chosen because it is susceptible to gray leaf spot and typically produces rectangu- lar, necrotic lesions (16) that are easy to measure. After germination, seedlings were maintained in a greenhouse or growth chamber at temperatures between 25 and $30^{\circ} \mathrm{C}$ until they were ready for inoculation. Starting 1 month after emergence, a nutrient solution (21:5:20) was applied to each pot on a weekly basis for the duration of the experiment.

Fresh cultures of C. zeae-maydis were prepared using an isolate collected from naturally infected maize leaves in Iowa. Cultures were prepared and maintained as described by Thorson and Martinson (39). Conidia were harvested by flooding petri dishes with a solution of Tween 20 and distilled water $(1 \mathrm{drop} / 500 \mathrm{ml})$ and dislodging the conidia with a small paintbrush. The resulting suspension was filtered through two layers of cheesecloth and brought to the final volume with distilled water. The spore concentration was estimated using a hemacytometer. A conidial suspension containing approximately 4 to $7 \times 10^{4}$ conidia $\mathrm{ml}^{-1}$ was atomized onto both surfaces of the leaves of maize plants at the V5 to V6 growth stage. Two to three spray passes were made at a distance of approximately $15 \mathrm{~cm}$ from the leaf surface so as to produce a uniform distribution of droplets without runoff. Inoculated plants were placed in transparent plastic bags and incubated in a growth chamber at 25 to $28^{\circ} \mathrm{C}$ and $100 \%$ relative humidity under a 14-h photoperiod. After 36 to $40 \mathrm{~h}$, the plants were removed from the bags and kept in the same growth chamber until symptoms developed. As soon as the first characteristic lesions of gray leaf spot were observed (10 to 21 days after inoculation), the plants were transferred to similar growth chambers maintained at 25,30 , or $35^{\circ} \mathrm{C}$ and exposed to a $14-\mathrm{h}$ photoperiod for the duration of the experiment. Six to seven pots, each containing two or three plants, were assigned randomly to each growth chamber.

Lesion expansion was assessed at 4-day intervals for 17 days (prior to leaf senescence). The same lesions were measured at each assessment. At the time of the first assessment, 10 lesions were selected from 7 to 10 numbered plants from each growth chamber. The positions of lesions relative to the leaf blade, base, tip, and midrib were recorded. A record also was made of the position of the leaf on the plant (third, fourth, or occasionally fifth leaf counting from the bottom). Lesion dimensions were measured in two perpendicular directions (primarily on the third and fourth leaves from the bottom) and used to determine lesion area (length by width) at each time.

Sporulation experiment. The effect of temperature and relative humidity on sporulation of C. zeae-maydis was assessed on leaves of Pioneer Brand hybrid 3394. Diseased leaves were harvested from adult maize plants from naturally infected cornfields in Iowa during the 2001 and
2002 growing seasons. Leaves were washed in running tap water and blotted dry. Typical, well-developed gray leaf spot lesions were excised, measured using a standard 30-cm ruler, surface disinfested in a $10 \%$ solution of bleach for $2 \mathrm{~min}$, rinsed in sterile distilled water, and blotted and air dried. Approximately $3 \mathrm{~cm}^{2}$ of diseased leaf tissue was assigned randomly to each temperature and relative humidity treatment combination.

Growth chambers, distilled water, and saturated salts solutions were used to achieve constant temperatures and relative humidities. Approximately $150 \mathrm{ml}$ of saturated salt solutions $(13,44)$ were placed into 10-by-10-by-5-cm transparent chambers (Show Box; Althor Products, Bethel, CT) to provide relative humidities of $70 \%$ $(1: 1$ mixture of $\mathrm{NaCl}+\mathrm{KCl}), 80 \%$ $\left(\left(\mathrm{NH}_{4}\right)_{2} \mathrm{SO}_{4}\right)$, and $90 \%\left(\mathrm{MgSO}_{4}\right.$ at 20 and $25^{\circ} \mathrm{C}$, and $\mathrm{KNO}_{3}$ at $30^{\circ} \mathrm{C}$ ). Distilled water provided $100 \%$ relative humidity. Prior to the experiment, the relative humidity at each salt solution-temperature combination was monitored using HOBO dataloggers (Model RH Stowaway; Spectrum Technologies Inc., Plainfield, IL) sealed inside of each chamber. Once the desired temperature and relative humidity were achieved, chambers were fitted with shelves (made of transparent acrylic plastic sheet) upon which open petri dishes containing excised leaf tissues were placed. An indicator card (Sud-Chemie Performance Packaging, Colton, CA) was affixed to the inside of the lid of each chamber to monitor relative humidity during the experiment. Each card was manufactured with a graduated humidity indicator strip (impregnated with a chemical) which changed from blue (dry) to pink (wet) as humidity increased. The humidity chambers were sealed airtight and randomly assigned (five per relative humidity treatment) to each of three growth chambers set at constant temperatures of 20,25, and $30^{\circ} \mathrm{C}$. Five additional sets of lesions were placed into separate humidity chambers containing distilled water $(100 \%$ relative humidity) and incubated at $35^{\circ} \mathrm{C}$. During this study, the saturated salt solutions and distilled water were replaced or replenished as necessary.

Following 3 days of incubation, leaf tissues were removed from the humidity chambers, placed into small vials containing a 5-ml solution of distilled water amended with Tween 20 (1 drop/500 ml), and vortexed for $1 \mathrm{~min}$ to dislodge conidia. A hemacytometer was used to estimate the conidial concentration in each replicate. The number of conidia produced in each unit area of diseased leaf tissue $\left(S_{\mathrm{A}}\right)$ was estimated as $S_{\mathrm{A}}=(S C \times V) / A$, where $S_{\mathrm{A}}=$ conidia per square centimeter, $S C=$ spore concentration (conidia per milliliter), $V=$ volume used to dislodge conidia (in milliliters), and $A=$ diseased leaf area (in square centimeters). 
Experimental design and data analysis. A randomized complete block design was used for the lesion expansion experiment. Each growth chamber constituted an experimental unit replicated over time, with temperature being the treatment randomly assigned to each unit. For the sporulation experiment, a split-plot design was used with temperature as the mainplot effect and relative humidity as the subplot effect. Each sporulation experiment consisted of 13 treatment combinations (three temperatures $\times$ four relative humidity levels + one $35^{\circ} \mathrm{C}-100 \%$ relative humidity treatment combination) and a total of 65 observations. Both the lesion expansion and the sporulation experiments were repeated three times.

SAS Proc Mixed (SAS Institute, Cary, NC) was used to analyze the data from all experiments. Prior to the analysis, both lesion area and spore production per unit lesion area $\left(S_{\mathrm{A}}\right)$ were $\log$-transformed to stabilize variance. A split-plot analysis of variance (ANOVA) was used to determine the main and interaction effects of temperature and relative humidity on the $\log$ of $S_{\mathrm{A}}$. Repeated-measures ANOVA (25) and linear mixed-model analysis of covariance (26) were performed to determine the effect of temperature on lesion area and the rate of lesion expansion over time. Temperature, time (day), and their interaction were treated as qualitative factors and fixed effects in the analysis of variance. Block was considered a random effect. Day was a temporal repeated measure. In the analysis of covariance, time was treated as a continuous covariate. Fixed effects were evaluated with $F$ tests based on Wald statistics, whereas random effects were evaluated with standard normal test statistics. A total of 125 observations (three experiments $\times$ three temperatures $\times$ three replicates $\times 5$ days) were used in the analysis.

Quadratic regression analysis was performed using SAS Proc REG to model the relationship between temperature and spore production at $100 \%$ relative humidity. Log-transformed $S_{\mathrm{A}}$ at $100 \%$ relative humidity was regressed against temperature for each experiment and for the pooled data set. A total of 20 observations (four temperatures $\times$ five replicates) were used to fit the models to the data from each experiment, whereas 60 observations were used to fit the model to the pooled data (three experiments $\times$ four temperatures $\times$ five replicates). In a separate analysis involving three levels of temperature $(20,25$, and $30^{\circ} \mathrm{C}$ ) and four levels of relative humidity (70, 80, 90, and 100\%), S-Plus 6.1 (Academic Site Edition, Insightful Corp. Seattle) was used to perform loess nonparametric regression analyses of the pooled data to model the relationship among temperature, relative humidity, and the $\log$ of $S_{\mathrm{A}}$. Coefficient of determination $\left(R^{2}\right)$ and $t$ test of significance of the regression coefficients were used as measures of goodness-of-fit of the quadratic models, whereas multiple $R^{2}$, residual plots, and correlation between predicted and actual sporulation were used as measures of goodness-of-fit of the loess nonparametric regression model.

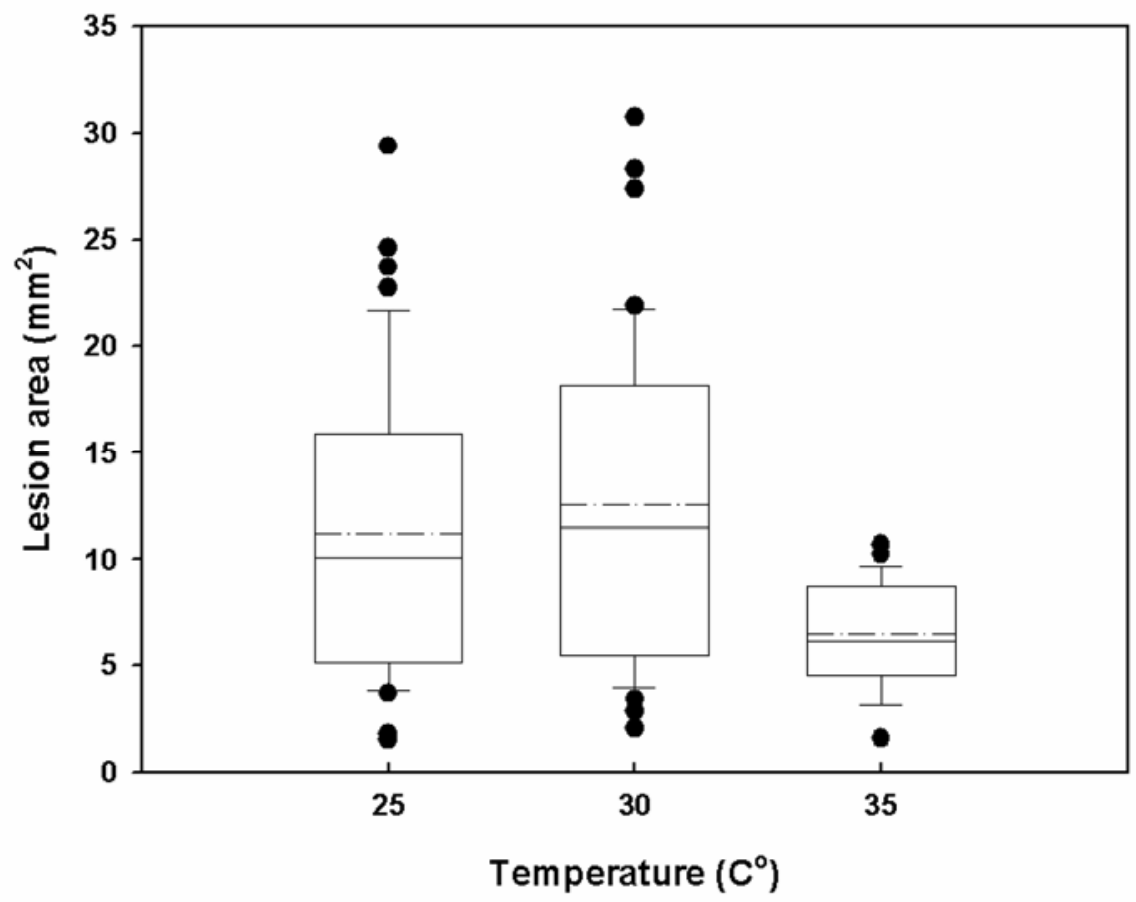

Fig. 1. Box plots summarizing the distribution of gray leaf spot of maize (inbred B73) lesion area for different temperature treatments $\left(25,30\right.$, and $\left.35^{\circ} \mathrm{C}\right)$. The broken and solid lines within the box represent the mean and median, respectively, while the top and bottom lines of the box represent the 75th and 25th percentiles of the data, respectively. Vertical bars extending beyond the boxes represent the 10 th and 90th percentiles, and circles indicate outliers.

\section{RESULTS}

Lesion expansion. Typical gray leaf spot lesions first were observed between 10 and 21 days after inoculation. The initial lesions were rectangular with a light brown appearance and averaged between 2 and $6 \mathrm{~mm}^{2}$ in area. Mean lesion area ranged from 1.57 to $29.38 \mathrm{~mm}^{2}$ at $25^{\circ} \mathrm{C}$, 2.10 to $30.77 \mathrm{~mm}^{2}$ at $30^{\circ} \mathrm{C}$, and 1.6 to 10.7 $\mathrm{mm}^{2}$ at $35^{\circ} \mathrm{C}$ (Fig. 1). The largest measured lesions were 47,51 , and $20 \mathrm{~mm}^{2}$ at 25,30 , and $35^{\circ} \mathrm{C}$, respectively. At 25 and $30^{\circ} \mathrm{C}$, lesions expanded at a constant rate over a 17-day period, reaching a mean final area of 20 and $23 \mathrm{~mm}^{2}$, respectively, compared with $8.7 \mathrm{~mm}^{2}$ at $35^{\circ} \mathrm{C}$ (Fig. 2). For the first 4 days after initial lesions appeared, lesion area increased relatively rapidly at $35^{\circ} \mathrm{C}$ (similar to 25 and $30^{\circ} \mathrm{C}$ ). Thereafter, the rate of expansion decreased and remained low for the duration of the experiment, resulting in smaller lesions. After 17 days, lesions developed at 25 and $30^{\circ} \mathrm{C}$ were necrotic and rectangular with well-defined borders. Those developed at $35^{\circ} \mathrm{C}$ were somewhat irregular in shape with chlorotic borders.

In all three experiments, temperature had a significant effect on the log of lesion area $(P \leq 0.05)$. The data from the three experiments were pooled to determine the effect of temperature on the rate of lesion expansion. The estimated intercepts were similar among treatments, and pairwise differences between them were not statistically significant (Table 1). However, temperature did have a significant effect on the rate of lesion expansion over time, as indicated by the estimated regression slopes. The rates differed among treatments, with the highest and lowest rates occurring at 30 and $35^{\circ} \mathrm{C}$, respectively. Pairwise differences between slopes at 25 and $35^{\circ} \mathrm{C}$ and at 30 and $35^{\circ} \mathrm{C}$ were significant; however, differences in slopes between 25 and $30^{\circ} \mathrm{C}$ were not significant (Table 1).

Sporulation. C. zeae-maydis produced conidia under all of the temperature and relative humidity conditions used in this study. However, spore production was strongly influenced by both factors and depended on the interaction between them. The interaction between temperature and relative humidity was highly significant $(P$ $\leq 0.05$ ). At a relative humidity between 70 and $90 \%$, sporulation was equally low at all temperatures. At $100 \%$ relative humidity, significantly more conidia were produced at 25 and $30^{\circ} \mathrm{C}$ than at $20^{\circ} \mathrm{C}$ (Table 2). In general, spore production was most abundant at $25^{\circ} \mathrm{C}$ and least abundant at 20 and $35^{\circ} \mathrm{C}$. The only exception was in experiment 3 , when sporulation was significantly greater at 30 than at $25^{\circ} \mathrm{C}$. Significantly more conidia were produced at 25 than at $30^{\circ} \mathrm{C}$ in experiment 1 ; however, in experiment 2 , the mean difference between these two treatments was not significant (Table 2).

In general, the quadratic model fit all four data sets well. All of the fitted models 
had relatively high coefficients of determination $\left(R^{2}\right)$ and highly significant $F$ values. The regression coefficients $\left(b_{0}, b_{1}\right.$, and $\left.b_{2}\right)$ all were highly significant $(P \leq 0.05$; Table $3)$. The model of the pooled data explained $63 \%$ of the variation in log of conidia per square centimeter of diseased leaf tissue with variation in temperature. Using the equation from this model to estimate sporulation at $100 \%$ relative humidity as a function of temperature, sporulation in- creased with temperature, reaching a maximum at approximately $27.2^{\circ} \mathrm{C}$, and then decreased, reaching a minimum at $35^{\circ} \mathrm{C}$ (Fig. 3). At the optimum temperature, the mean number of conidia produced per square centimeter of lesion was more than 16,000 .

When fitted to the pooled data, the loess nonparametric regression model described $84 \%$ of the variation in the log of conidia per square centimeter of lesion as a func-

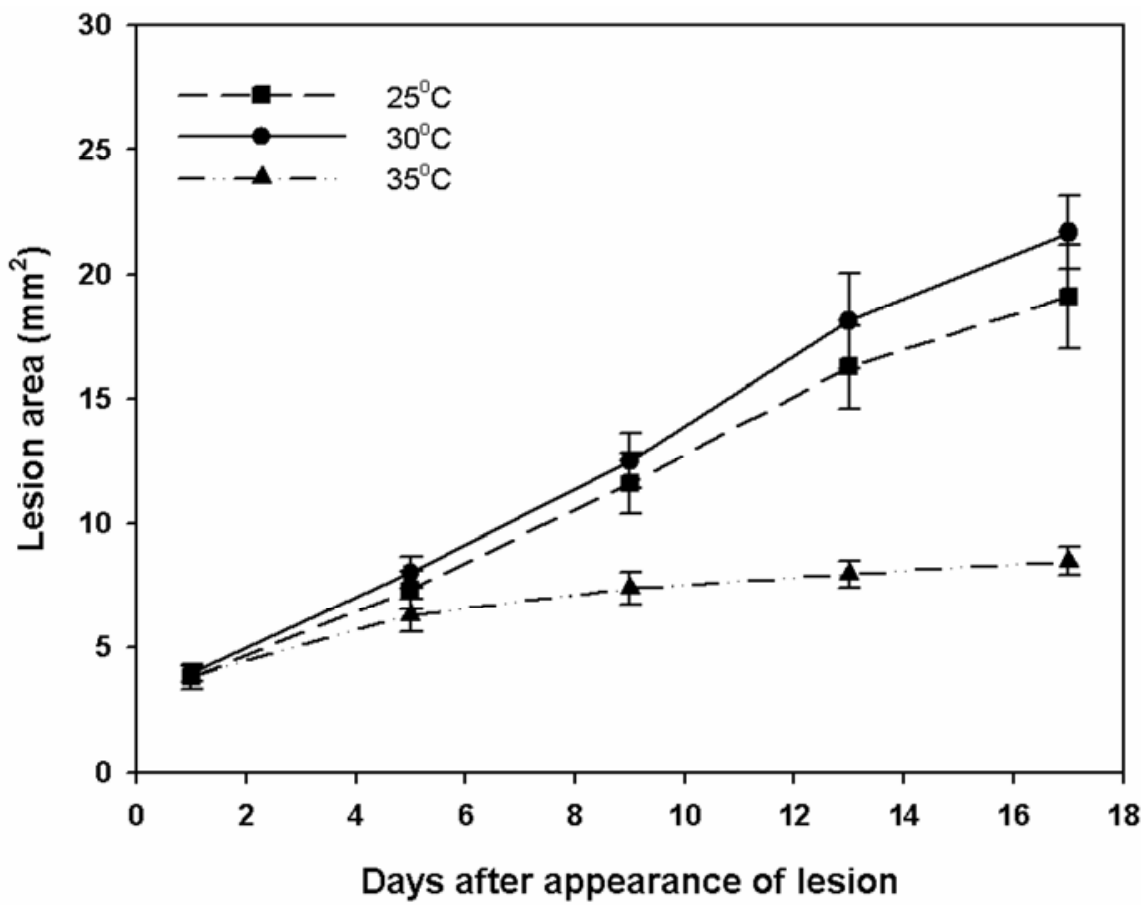

Fig. 2. Mean lesion area for gray leaf spot on leaves of maize inbred B73 during a 17-day incubation at 25,30 , and $35^{\circ} \mathrm{C}$ following artificial inoculation with Cercospora zeae-maydis. Temperature treatments were imposed after initial lesion formation was observed. Each point represents the mean of 90 lesions (three experiments $\times$ three replications $\times 10$ lesions/replication), and the vertical bars indicate the standard error of the mean at each time. tion of temperature and relative humidity. The residual standard error was 0.22 . Diagnostic plots of the residuals against each predictor showed that the model was appropriate for explaining sporulation as a function of temperature and relative humidity. No lack of fit was evident from these plots. The three-dimensional plot of predicted log-transformed conidia production per square centimeter of diseased tissue clearly indicated a strong interaction between temperature and relative humidity (Fig. 4). Optimum temperature for spore production at relative humidity $>95 \%$ was between 25 and $27^{\circ} \mathrm{C}$. Below $95 \%$ relative humidity, spore production was low regardless of temperature. The correlation between back-transformed model estimates and actual spore production was high $(r=0.98)$.

\section{DISCUSSION}

The results of this study indicate that temperature affects both gray leaf spot lesion expansion and sporulation of $C$. zeae-maydis on diseased maize leaves. The influence of temperature on sporulation, however, depends on relative humidity. In spite of the relatively high spore production at $70 \%$ relative humidity and $20^{\circ} \mathrm{C}$ (Fig. 4), sporulation at this treatment combination was not significantly different from sporulation at other treatment combinations involving relative humidities below $100 \%$. The effect of temperature was only significant at $100 \%$ relative humidity. At $100 \%$ relative humidity, the optimum temperature for sporulation was between 25 and $30^{\circ} \mathrm{C}$. Similarly, the highest rates of lesion expansion were observed at 25 and $30^{\circ} \mathrm{C}$. Both lesion development and sporulation were minimal at $35^{\circ} \mathrm{C}$.

Table 1. Estimated slopes, intercepts, and pairwise differences between slopes and intercepts and their corresponding standard errors (SEs) for the effect of temperature on the change in the log of lesion area over time ${ }^{\mathrm{a}}$

\begin{tabular}{|c|c|c|c|c|c|c|}
\hline Treatment $\left({ }^{\circ} \mathbf{C}\right)^{\mathbf{b}}$ & Slope & SE & $P$ value & Intercept & SE & $P$ value \\
\hline \multicolumn{7}{|c|}{ Estimated slopes and intercepts } \\
\hline 25 & 0.107 & 0.007 & $<0.001$ & 1.190 & 0.135 & $<0.001$ \\
\hline 30 & 0.115 & 0.007 & $<0.001$ & 1.255 & 0.135 & $<0.001$ \\
\hline 35 & 0.058 & 0.007 & $<0.001$ & 1.202 & 0.135 & $<0.001$ \\
\hline \multicolumn{7}{|c|}{ Estimated pairwise differences } \\
\hline $30-25$ & 0.008 & 0.010 & 0.422 & 0.065 & 0.120 & 0.593 \\
\hline $25-35$ & 0.049 & 0.010 & $<0.001$ & -0.012 & 0.120 & 0.918 \\
\hline $30-35$ & 0.056 & 0.010 & $<0.001$ & 0.052 & 0.120 & 0.665 \\
\hline
\end{tabular}

${ }^{a}$ Lesions were measured on the leaves of inbred B73 subsequent to artificial inoculation.

${ }^{\mathrm{b}}$ Temperature treatments were imposed after initial lesion formation was observed.

Table 2. Estimated difference in mean sporulation of Cercospora zeae-maydis per square centimeter of gray leaf spot lesion excised from naturally infected leaves of Pioneer Brand hybrid $3394^{\mathrm{a}}$

\begin{tabular}{|c|c|c|c|c|c|c|}
\hline \multirow[b]{2}{*}{ Mean comparison $\left({ }^{\circ} \mathrm{C}\right)$} & \multicolumn{2}{|c|}{ Experiment 1} & \multicolumn{2}{|c|}{ Experiment 2} & \multicolumn{2}{|c|}{ Experiment 3} \\
\hline & Estimate & $P$ value & Estimate & $P$ value & Estimate & $P$ value \\
\hline $25-20$ & 0.77 & $<0.001$ & 1.04 & $<0.001$ & 0.98 & $<0.001$ \\
\hline $30-20$ & 0.28 & 0.071 & 0.79 & $<0.001$ & 1.29 & $<0.001$ \\
\hline $25-30$ & 0.49 & 0.002 & 0.25 & 0.130 & -0.31 & 0.036 \\
\hline
\end{tabular}

${ }^{\mathrm{a}}$ Lesions were subjected to temperatures between 20 and $30^{\circ} \mathrm{C}$ at $100 \%$ relative humidity for $72 \mathrm{~h}$. Estimate $=$ difference in spore production $(\log [([\mathrm{conidia}$ per square centimeter]/1,000) + 1]) of diseased leaf area between temperature treatments. 
Temperature and relative humidity responses observed in this study were comparable with those reported for other developmental processes of C. zeae-maydis. Studying the effect of temperature on germination of conidia and elongation of germ tube of C. zeae-maydis exposed to 12 $\mathrm{h}$ of high relative humidity, Beckman and Payne (3) observed that the optimum temperature was between 22 and $30^{\circ} \mathrm{C}$ and no germination occurred at $36^{\circ} \mathrm{C}$. Temperatures between 25 and $30^{\circ} \mathrm{C}$ appeared to favor the growth of $C$. zeae-maydis, resulting in greater colonization of healthy tissue from the adjacent diseased tissue, thus leading to greater lesion expansion. At $35^{\circ} \mathrm{C}$, restricted lesions with distinct chlorotic borders developed. This type of lesion development is typical of a resistance reaction. This is contrary to what is known to occur on inbred B73 (16). Our data suggest that, at $35^{\circ} \mathrm{C}$, the fungus is less capable of growth and colonization of plant tissue. The findings of Garden and Hilty (18) on effects of temperature on radial growth of $C$. zeae-maydis on potato dextrose agar support this hypothesis. They observed that neither sporulation nor radial growth occurred at $32^{\circ} \mathrm{C}$.

In addition to temperature, several other factors (held constant in this study) may affect lesion expansion under natural conditions. These include leaf position and plant age $(2,14)$, lesion age $(6,42)$, relative humidity, density and proximity of lesions on the leaf (35), isolate or race of the pathogen $(27,37)$, and host resistance $(6,14,16,20,27,31,35)$. Characterizing the lesion response by maize to $C$. zeae-maydis, Freppon et al. (16) reported three distinct types of lesions based on the resistance of the genotypes studied: restricted lesions with chlorosis, typical of a resistance reaction; rectangular necrotic lesions, characteristic of a susceptible reaction; and irregular chlorotic flecks. The same isolate of $C$. zeaemaydis was used to inoculate the same susceptible inbred (B73) at the same growth stage (V5 to V6) in all experiments of this study; therefore, several of these confounding effects were minimized. However, given the fact that lesions appeared between 10 and 21 days after inoculation, the effect of plant or leaf age may have been partly responsible for the variability in lesion expansion observed across experiments.

Other species of Cercospora were reported to have responses to temperature and relative humidity similar to those observed for C. zeae-maydis in this study. On peanut leaves incubated at $100 \%$ relative humidity, sporulation (conidia per square millimeter of diseased tissue) of $C$. arachidicola was greatest at 24 and $28^{\circ} \mathrm{C}$, intermediate at $20^{\circ} \mathrm{C}$, and lowest at 16 and $32^{\circ} \mathrm{C}$ (1). Similar results were reported by Gobina and Melouk (19). Alderman and Beute (1) observed that sporulation of $C$. arachidicola declined with decreasing water potential of lesions from -0.05 to $-6.0 \mathrm{MPa}$, and increased with cyclic wet $(100 \%$ relative humidity) or dry $(75 \%$ relative humidity) regimes as the number of hours of wetness increased. Sporulation of $C$. carotae on carrot leaves increased with increasing temperature up to the op- timum of $28^{\circ} \mathrm{C}$, then decreased as temperature increased to $32^{\circ} \mathrm{C}$; however, no sporulation was observed at 16 and $32^{\circ} \mathrm{C}$ when relative humidity was $96 \%$ (7). Optimum temperature for sporulation of $C$. kikuchi (8), C. cruenta (15), and C. asparagi (9) in culture also were between 25 and $28^{\circ} \mathrm{C}$. For these species, these temperatures coincided with optimum temperatures for radial growth. Assessing the effects of relative humidity (at 23 to $25^{\circ} \mathrm{C}$ ) on microcycle conidiation (production of secondary conidia from primary conidia) in C. zeae-maydis, Lapaire and Dunkle (21) reported that, below $97 \%$ relative humidity, germ tube elongation and secondary conidiation ceased and only resumed when relative humidity was raised above $97 \%$ again.

Although distinct and consistent trends in the relationship among sporulation of $C$. zeae-maydis, temperature, and relative

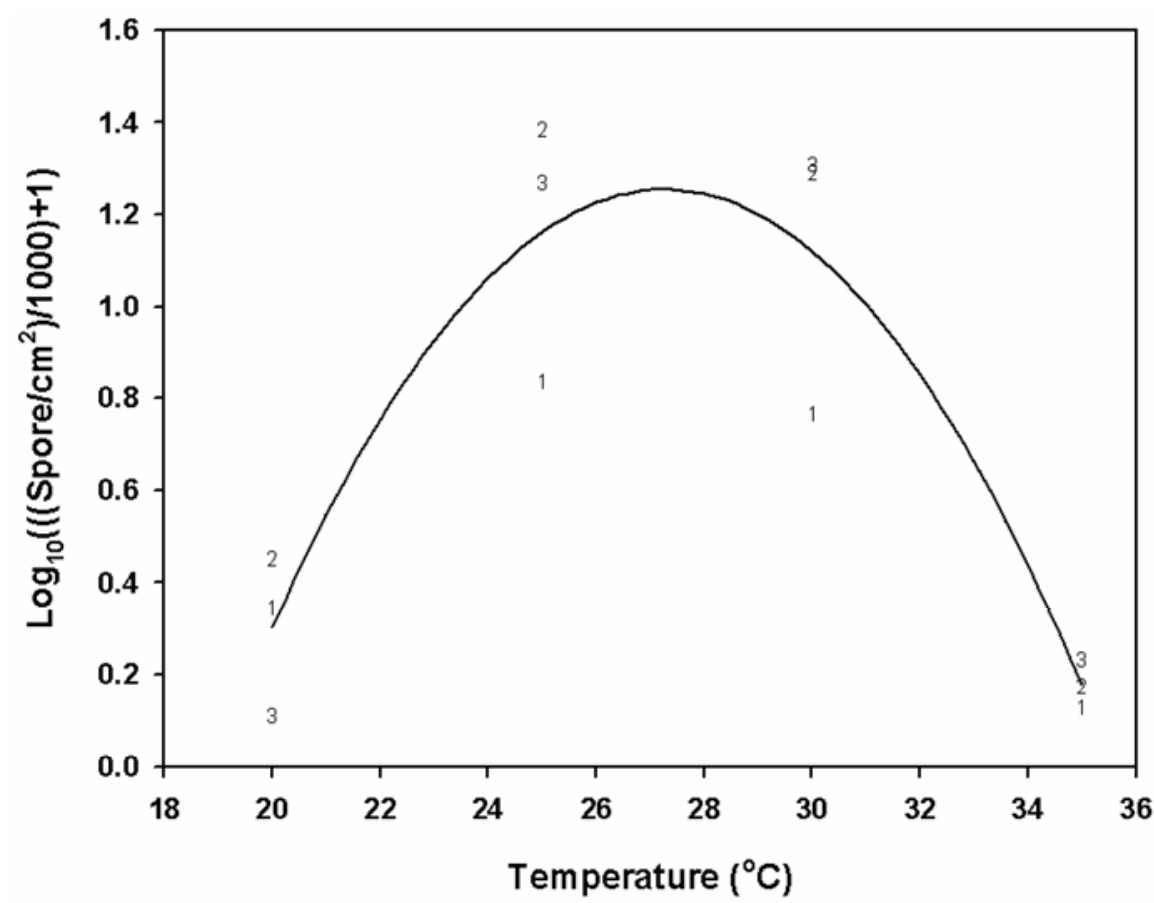

Fig. 3. Quadratic relationship between log-transformed conidia per square centimeter of gray leaf spot lesion and temperature. Conidia were counted on lesions excised from leaves of Pioneer Brand hybrid 3394 naturally infected with Cercospora zeae-maydis and incubated for $72 \mathrm{~h}$ at $100 \%$ relative humidity and 20 to $35^{\circ} \mathrm{C}$. The numbers 1,2 , and 3 represent three experiments and the solid line represents the pooled data of the three experiments. Each numbered point represents the mean of five replicates, whereas the line passes through the means of 15 observations (three experiments $\times$ five replicates) at each temperature.

Table 3. Summary of quadratic regression analysis of the effect of temperature on sporulation (log of conidia per square centimeter) of Cercospora zeaemaydis on naturally occurring maize leaf lesions (Pioneer Brand hybrid 3394) ${ }^{\mathrm{a}}$

\begin{tabular}{|c|c|c|c|c|c|c|c|}
\hline \multirow[b]{2}{*}{ Model $^{b}$} & \multirow[b]{2}{*}{ df $\mathbf{c}^{\mathrm{c}}$} & \multirow[b]{2}{*}{$\mathbf{S S}^{\mathbf{d}}$} & \multirow[b]{2}{*}{$R^{2}$} & \multirow[b]{2}{*}{$F P$-value } & \multicolumn{3}{|c|}{ Coefficient, $P$ value } \\
\hline & & & & & $\mathbf{b}_{0}$ & $\mathbf{b}_{1}$ & $\mathbf{b}_{2}$ \\
\hline Experiment 1 & 17 & 1.803 & 0.49 & 0.003 & $-7.26,0.004$ & $0.61,0.002$ & $-0.01,0.001$ \\
\hline Experiment 2 & 17 & 1.394 & 0.80 & $<0.001$ & $-13.53,<0.001$ & $1.11,<0.001$ & $-0.02,<0.001$ \\
\hline Experiment 3 & 17 & 1.938 & 0.76 & $<0.001$ & $-15.68,<0.001$ & $1.24,<0.001$ & $-0.02,<0.001$ \\
\hline Pooled & 57 & 7.25 & 0.63 & $<0.001$ & $-12.16,<0.001$ & $0.98,<0.001$ & $-0.02,<0.001$ \\
\hline
\end{tabular}

\footnotetext{
${ }^{\text {a }}$ Lesions were incubated at $100 \%$ relative humidity for $72 \mathrm{~h}$ at 20 to $35^{\circ} \mathrm{C}$.

${ }^{\mathrm{b}}$ Models were fitted to the $\log$-transformed sporulation $(\log [([$ conidia per square centimeter $] / 1,000)+1])$ for each experiment and the pooled data.

${ }^{\mathrm{c}}$ Error degrees of freedom.

${ }^{\mathrm{d}}$ Error sums of square.
} 
humidity were observed in this study, the variability between experiments still was very high. This probably was due to differences in maturity or age of the lesions used. Studying the effects of hybrid resistance on the sporulation capacity of $C$. zeae-maydis, Ringer and Grybauskas (32) attributed the high variability they observed in sporulation among samples to differences in sporulation among lesions of different maturity. Likewise, from their study of the survival of C. zeae-maydis in infected debris, de Nazareno et al. (10) concluded that high variability in conidial production was due partly to differences in lesion age. Beckman and Payne (3) reported that sporulation of $C$. zeae-maydis was limited to the necrotic area of lesions and began 1 to 3 days after lesions became necrotic (matured). The age of the leaves from which lesions were excised also might have affected spore production. Older leaves generally have more functional stomata per square centimeter than younger leaves (36) and, because conidiophores emerge through stomatal openings (22), more conidia are likely to be produced per unit area of lesion originating from older than younger leaves. Differences in stomatal density reportedly were responsible for significant differences in spore production between lesions from leaf blades and sheaths (10).

The effects of environment on expansion and sporulation of gray leaf spot lesions help to further explain the dynamics of the disease in the field. The expansion of existing lesions due to favorable mid- and lateseason temperatures may partially explain the rapid increase in gray leaf spot severity typically observed during the middle and latter parts of the growing season. Once relative humidity is above $95 \%$, expanding lesions may serve as a source of inoculum for secondary infection under a wide range of temperatures. Even with very few secondary cycles, final gray leaf spot severity may be very high if high levels of infection occur during the first few cycles and conditions are favorable for the rapid expansion of primary lesions. This information may be useful for gray leaf spot management through simulation or prediction modeling. The regression equations for lesion expansion and sporulation from this study may be used in the development of process-based models for this disease. However, further investigations are needed to determine how the relationships reported herein may be influenced by other environment- and genotype-related factors not accounted for in this study.

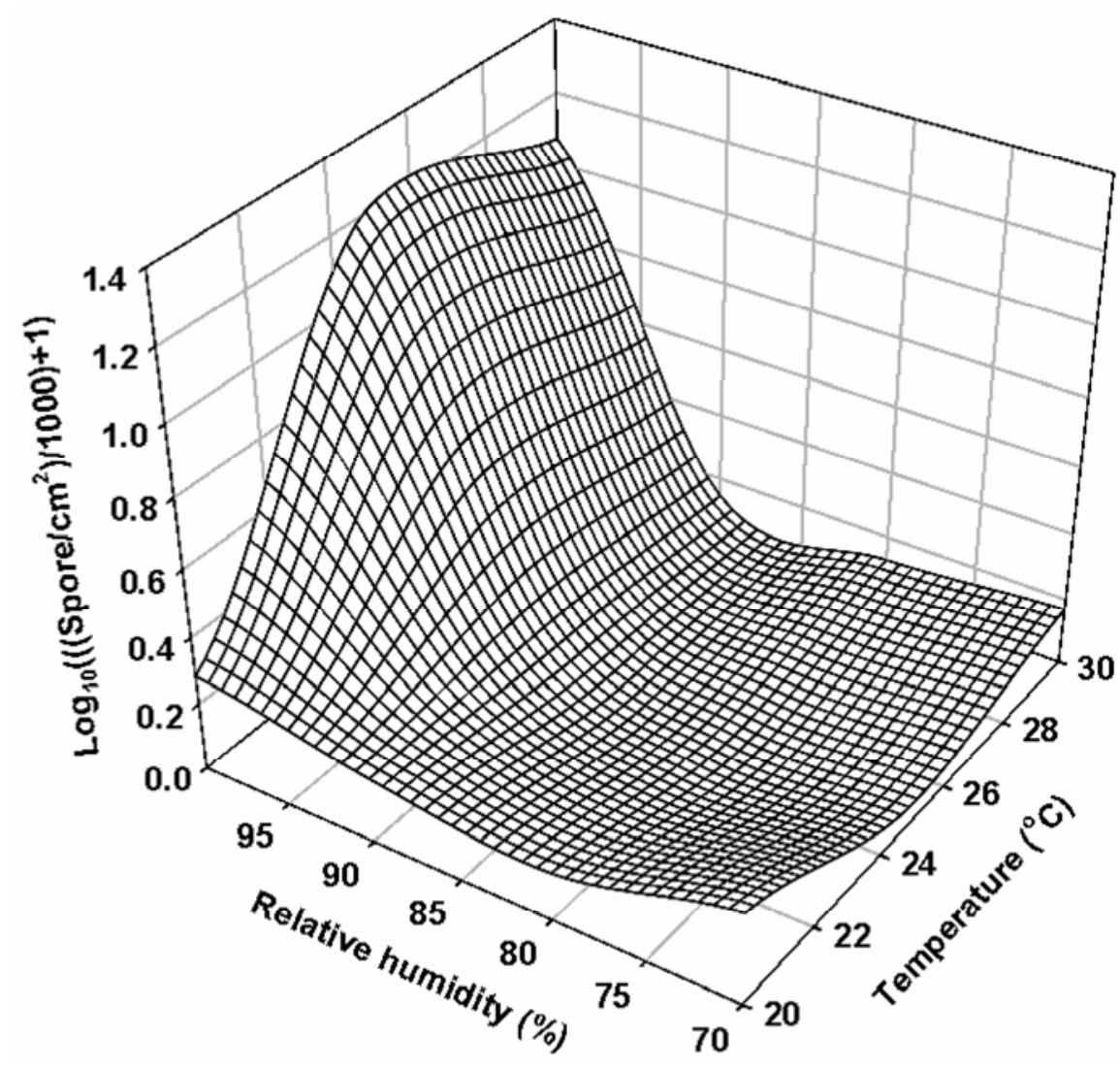

Fig. 4. Response surface of the log of conidia per square centimeter of gray leaf spot lesion as a function of temperature and relative humidity. Conidia were counted on lesions excised from leaves of Pioneer Brand hybrid 3394 naturally infected with Cercospora zeae-maydis and incubated for $72 \mathrm{~h}$ at 70 to $100 \%$ relative humidity and 20 to $30^{\circ} \mathrm{C}$. The plot was generated using values predicted from the fitted loess nonparametric regression model. The model was fitted using 36 observations (three experiments $\times 12$ treatment combinations).
ACKNOWLEDGMENTS

We thank F. W. Nutter, Jr. of the Department Plant Pathology at Iowa State University and P. E. Lipps and M. A. Ellis of the Department Plant Pathology at The Ohio State University for critically reviewing this manuscript. This research was partially supported by Pioneer Hi-Bred Int., Inc., and the USDA North Central IPM Program.

\section{LITERATURE CITED}

1. Alderman, S. C., and Beute, M. K. 1987. Influence of temperature, lesion water potential, and cyclic wet-dry periods on sporulation of Cercospora arachidicola on peanut. Phytopathology 77:960-963.

2. Aust, H. J., Hau, B., and Kranz, J. 1983. EPIGRAM-A simulator of barley powdery mildew. Z. Pflanzenkrankh. Pflanzenschutz 90:244-250.

3. Beckman, P. M., and Payne, G. A. 1982. External growth, penetration, and development of Cercospora zeae-maydis in corn leaves. Phytopathology 72:810-815.

4. Beckman, P. M., and Payne, G. A. 1983. Cultural techniques and conditions influencing growth and sporulation of Cercospora zeaemaydis and lesion development in corn. Phytopathology 73:286-289.

5. Berger, R. D., Bergamin Filho, A., and Amorim, L. 1997. Lesion expansion as an epidemic component. Phytopathology 87:1005-1013.

6. Bruhn, J. A., and Fry, W. E. 1981. Analysis of potato late blight epidemiology by simulation modeling. Phytopathology 71:612-616.

7. Carisse, O., Kushalappa, A. C., and Cloutier, D. C. 1993. Influence of temperature, leaf wetness, and relative humidity duration on sporulation of Cercospora carotae on carrot leaves. Phytopathology 83:338-343.

8. Chen, M. D., Lyda, S. D., and Halliwell, R. S 1979. Environmental factors influencing growth and sporulation of Cercospora kikuchii. Mycologia 71:1150-1157.

9. Cooperman, C. J., and Jenkins, S. F. 1986 Conditions influencing growth and sporulation of Cercospora asparagi and Cercospora blight development in asparagus. Phytopathology 76:617-622.

10. de Nazareno, N. R. X., Lipps, P. E., and Madden, L. V. 1992. Survival of Cercospora zeaemaydis in corn residue in Ohio. Plant Dis. 76:560-564.

11. de Nazareno, N. R. X., Lipps, P. E., and Madden, L. V. 1993. Effect of levels of corn residue on the epidemiology of gray leaf spot of corn in Ohio. Plant Dis. 77:67-70.

12. de Nazareno, N. R. X., Madden, L. V., and Lipps, P. E. 1993. Characterization of gray leaf spot epidemics of maize. J. Plant Dis. Prot. 100:410-425.

13. Dhingra, O. D., and Sinclair, J. B. 1995. Basic Plant Pathology Methods, 2nd ed. CRC Press, Inc., Boca Raton, FL.

14. Emge, R. G., Kingsolver, C. H., and Johnson, D. R. 1975. Growth of the sporulating zone of Puccinia striiformis and its relationship to stripe rust epiphytology. Phytopathology 65:679-681.

15. Fahim, M. M., Abibu, Y. A., Abdelal, H. R., and Moustafa, Y. A. 1979. Some nutritional and environmental factors affecting growth and sporulation of Cercospora cruenta. Egypt. J. Phytopathol. 10:77-84.

16. Freppon, J. T., Lipps, P. E., and Pratt, P. C. 1994. Characterization of the chlorotic lesion response by maize to Cercospora zeae-maydis. Plant Dis. 78:945-949.

17. Freppon, J. T., Pratt, P. C., and Lipps, P. E. 1996. Chlorotic lesion response of maize to Cercospora zeae-maydis and its effect on gray leaf spot disease. Phytopathology 86:733-738.

18. Garden, F. T., and Hilty, J. W. 1981. The effect of temperature and substrate on growth and 
sporulation of Cercospora zeae-maydis on agar media. J. Tenn. Acad. Sci. 56:60-63.

19. Gobina, S. M, and Melouk, H. A. 1981. Effect of temperature on the sporulation and conidial germination of Cercospora arachidicola. (Abstr.) Phytopathology 71:876.

20. Gordon, S. G. 2002. Genetic Mapping and components of resistance to Cercospora zeaemaydis in maize. Ph.D. diss. The Ohio State University, Wooster.

21. Lapaire, C. L., and Dunkle, L. D. 2003. Microcycle conidiation in Cercospora zeae-maydis. Phytopathology 93:193-199.

22. Latterell, F. M., and Rossi, A. E. 1983. Gray leaf spot of corn: a disease on the move. Plant Dis. 67:842-847.

23. Leonard, K. J. 1974. Foliar pathogens of maize in North Carolina. Plant Dis. Rep. 58:532-534.

24. Lipps, P. E. 1998. Gray leaf spot: A global threat to corn production. APSNet Feature. Online publication, May 1998. The American Phytopathological Society, St. Paul, MN.

25. Littell, R. C., Henry, P. R., and Ammerman, C. B. 1998. Statistical analysis of repeated measures data using SAS procedures. J. Anim. Sci. 76:1216-1231.

26. Littell, R. C., Milliken, G. A., Stroup, W. W., and Wolfinger, R. D. 1996. SAS System for Mixed Models. SAS Institute, Cary, NC.

27. Mehta, Y. R. 1981. Producao de conidios, periodo de esporulacao e extencao da lesao por Helminthosporium sativum nas folhasbaixeiras de trigo. Pesqui. Agropecu. Bras. 16:77-79.
28. Paul, P. A. 2003. Epidemiology and predictive management of gray leaf spot of maize. Ph.D. Diss. Iowa State University, Ames.

29. Payne, G. A., Duncan, H. E., and Adkins, C. R. 1987. Influence of tillage on development of gray leaf spot and number of airborne conidia of Cercospora zeae-maydis. Plant Dis. 71:329332.

30. Payne, G. A., and Waldron, J. K. 1983. Overwintering and spore release of Cercospora zeae-maydis in corn debris in North Carolina. Plant Dis. 67:87-89.

31. Prates, L. G., and Fernandes, J. M. C. 2001. Avaliando a taxa de expansao de lesoes de $B i$ polaris sorokiniana em trigo. Fitopatol. Bras. 26:185-191.

32. Ringer, C. E., and Grybauskas, A. P. 1995. Infection cycle components and disease progress of gray leaf spot on field corn. Plant Dis. 79:24-28.

33. Rupe, J. C., Siegel, M. R., and Hartman, J. R. 1982. Influence of environment and plant maturity on gray leaf spot of corn caused by $\mathrm{Cer}$ cospora zeae-maydis. Phytopathology 72:1587-1591.

34. Sall, M. A. 1980. Epidemiology of grape powdery mildew: A model. Phytopathology 70:338-342.

35. Shaner, G. 1983. Growth in uredinia of Puccinia recondita in leaves of slow- and fastrusting wheat cultivars. Phytopathology 73:931-935.

36. Smith, K. L. 1989. Epidemiology of gray leaf spot of field corn (Zea mays L.) caused by
Cercospora zeae-maydis Tehon \& Daniels. Ph.D. diss. University of Maryland, College Park.

37. Subbarao, K. V., and Michailides, T. J. 1995. Effects of temperature on isolates of Fusarium moniliforme causing fig endosepsis and Asper gillus niger causing smut. Phytopathology 85:662-668.

38. Tehon, L. R., and Daniels, E. 1925. Notes on parasitic fungi of Illinois. Mycologia 17:240 249.

39. Thorson, P. R , and Martinson, C. A. 1993. Development and survival of Cercospora zeae-maydis germlings in different relative humidity environments. Phytopathology 83:153-157.

40. Vanderplank, J. E. 1963. Plant Disease: Epidemics and Control. Academic Press, New York.

41. Waggoner, P. E., and Horsfall, J. G. 1969 EPIDEM, a simulator of plant disease written for a computer. Bull. Conn. Agric. Exp. Stn. New Haven 698.

42. Waggoner, P. E., Horsfall, J. G., and Lukens, R. J. 1972. EPIMAY, a simulator of southern corn leaf blight. Bull. Conn. Agric. Exp. Stn. New Haven 729.

43. Ward, J. M. J., Stromberg, E. L., Nowell, D. C., and Nutter, F. W., Jr. 1999. Gray leaf spot: a disease of global importance in maize production. Plant Dis. 83:884-895.

44. Winston, P. W., and Bates, D. H. 1960. Saturated salt solutions for control of humidity in biological research. Ecology 41:232. 